\title{
Rheumatoid Factors from the Peripheral Blood of Two Patients with Rheumatoid Arthritis Are Genetically Heterogeneous and Somatically Mutated
}

Kathy Youngblood, Lori Fruchter, Guifeng Ding, Javier Lopez, Vincent Bonagura, and Anne Davidson

Departments of Medicine, Microbiology, and Immunology and Pediatrics, Albert Einstein College of Medicine, Bronx, New York 10461

\begin{abstract}
We report the DNA sequences of the heavy and light chain immunoglobulin genes of 11 monoclonal rheumatoid factor (RF)-secreting lines derived from the peripheral blood of two patients with rheumatoid arthritis (RA). It is evident from immunogenetic analysis of these lines that RA-associated RF activity can arise from a wide variety of heavy and light chain genes and gene combinations. Although the RF response from our two patients shows a bias in gene usage toward those genes used to encode monoclonal RF, particularly VkIII, relatively few of these RFs are reactive with the monoclonal antiidiotypes 6B6.6 and 17.109 that define VkIII germline-encoded light chains and the loss of this idiotypic reactivity is clearly related to somatic mutation. Finally, RFs derived from peripheral blood of RA patients show a similar heterogeneity of epitope binding to Fc as that seen for synovium-derived RF and some are clearly different in binding specificity from the restricted RF population found in patients with $B$ cell malignancies. Somatic mutations as well as different VH/VL combinations contribute to the heterogeneity in the binding patterns of these RA-derived RF. (J. Clin. Invest. 1994. 93:852-861.) Key words: idiotypes $\bullet$ immunoglobulin genes $\bullet$ rheumatoid arthritis - rheumatoid factor • somatic mutation
\end{abstract}

\section{Introduction}

Rheumatoid factors (RFs), ${ }^{1}$ defined as autoantibodies that bind epitopes on the Fc portion of $\operatorname{IgG}(1)$, are thought to play a physiologic role in clearance of immune complexes, antigen presentation, and/or B cell regulation in normal individuals (2-6). In addition, a high proportion of monoclonal IgM antibodies derived from patients with $B$ cell malignancies and cryoglobulinemia have RF activity (2). In patients with rheumatoid arthritis (RA), where the presence of RF in serum is a hallmark of the disease, RFs are produced by the rheumatoid synovium and higher titers correlate with more aggressive disease (1). There is also substantial evidence that circulating im-

Address correspondence to Dr. Anne Davidson, Department of Rheumatology, U505, Albert Einstein College of Medicine, 1300 Morris Park Avenue, Bronx, NY 10461.

Received for publication 7 June 1993 and in revised form 17 September 1993.

1. Abbreviations used in this paper: $\mathrm{CDR}$, complementarity determining region; FR, framework region; H/L, heavy/light (chain); RF, rheumatoid factor; R:S, replacement to silent ratio (of mutations); SS, single-stranded.

J. Clin. Invest.

(c) The American Society for Clinical Investigation, Inc.

$0021-9738 / 94 / 02 / 0852 / 10 \quad \$ 2.00$

Volume 93, February 1994, 852-861 mune complexes involving RF can be pathogenic in some patients with $\mathrm{RA}(1,7,8)$.

Immunogenetic studies of the RF response in RA have focused on whether there is a bias in the RF repertoire toward usage of particular $\mathrm{V}$ region immunoglobulin genes, i.e., whether RFs are encoded by diverse germline genes, suggesting that the high titers in RA are a result of polyclonal B cell activation, or whether they are clonally related and somatically mutated in individual patients, suggesting a more specific antigen driven response (reviewed in reference 9 ). This issue can be addressed by analyses of idiotypic and fine structural specificity. Monoclonal RFs from patients with $B$ cell dyscrasias have restricted idiotypic specificities, with $60-80 \%$ expressing either the 17.109 or 6B6.6 idiotypes that are markers for the human VkIIIb subgroup gene Humkv 325 and VkIIIa subgroup gene Humkv $328(2,10,11)$. These light chains are preferentially associated with members of the VH1 and VH4 families, respectively $(12,13)$. However, the 17.109 and 6B6.6 idiotypes are expressed on only a small fraction of RF from RA patients (2, $11,14,15)$, suggesting either that the Humkv 325 and 328 genes are not used to encode a RF response in RA patients, or that somatic mutation of the variable regions has resulted in loss of these idiotypic specificities.

B cell lines producing monoclonal RFs have been derived from both RA peripheral lymphocytes and synovium and their immunoglobulin genes have been characterized (16-20, reviewed in reference 9). Study of these lines has shown that although RFs can be encoded by a diverse repertoire of antibody genes, there does appear to be an overrepresentation of the VH3 heavy chain genes and probably of the VkIIIa and VkIIIb light chain genes (9). Furthermore, patterns of mutation suggest that some of these RFs may be selected by antigen $(18,20)$. In one study of two clonally related RFs from a single individual, the higher affinity for $\mathrm{Fc}$ was seen in the more mutated RF of the pair (21).

In addition to the differences in idiotypic specificity between RFs from patients with B cell malignancies and RA-derived RFs, there are also differences in fine antigenic specificity. We studied monoclonal RFs derived both from synovial and peripheral B cell lines from RA patients and found that they have diverse antigenic specificities not found among malignancy-associated RFs $(22,23)$. The basis for these differences might relate to usage of diverse genes and gene combinations to encode RFs or, alternatively, to the presence of somatic mutations in the RFs from RA patients.

In this study we further examine the molecular genetic structures of the heavy and light chain genes of 11 IgM RFs derived from the peripheral blood of two patients with RA and correlate them with fine antigenic and idiotypic specificity. This study documents that in addition to the heavy/light $(\mathrm{H} /$ L) combinations typical of malignancy-associated RFs, a wide variety of unique $\mathrm{H} / \mathrm{L}$ combinations can be used to encode RF activity. Furthermore, we demonstrate that in some instances, 
somatic mutation is responsible both for loss of idiotypic activity and for alterations in fine antigenic specificity. The RF response in RA patients therefore reflects diversification mediated both by somatic mutation of genes that are used in the RFs of B cell malignancy and by recruitment of new genes and gene combinations.

\section{Methods}

Generation of B cell lines. Peripheral blood was obtained from two patients with RA as defined by American College of Rheumatology criteria. Both patients had erosive disease and both had active synovitis at the time of venipuncture. Patient $R$ was taking $5 \mathrm{mg}$ of prednisone and was on monthly intramuscular gold. Patient B was taking $5 \mathrm{mg}$ of prednisone daily and $10 \mathrm{mg}$ of methotrexate weekly. Lymphocytes were obtained by Ficoll-Hypaque separation of peripheral blood and were transformed with Epstein-Barr virus as previously described (24, 25 ). After $4 \mathrm{~d}$ the cells were cloned by limiting dilutions as previously described (24) and the clones were tested for IgM RF activity on purified $\mathrm{Fc}$ fragments of total human IgG by ELISA as previously described (26). Positive wells were expanded and recloned by limiting dilutions. Lines were tested for heavy and light chain isotype by ELISA. Microtiter wells were coated with $0.2 \mu \mathrm{g}$ of IgG Fc fragment in PBS, blocked with $5 \% \mathrm{FCS} / 1 \% \mathrm{BSA}$ for $90 \mathrm{~min}$ and then serially incubated with cell line supernatant for $1 \mathrm{~h}$, peroxidase-conjugated $\mathrm{F}(\mathrm{ab})^{\prime} 2$ goat antibodies for each of human IgA, IgM, IgG, $\kappa$ or $\lambda$ (Accurate Chemical \& Scientific Corp., Westbury, NY, and Fisher Scientific Co., Pittsburgh, PA) for $1 \mathrm{~h}$ and then 2,2'-azino-di-[ 3ethyl benzthiazoline sulfonate] substrate peroxidase substrate (Kirkegaard \& Perry Labs, Inc., Gaithersburg, MD).

Cell line supernatants were tested for reactivity with human $\mathrm{Fc}$, rabbit immunoglobulin, single-stranded (ss) DNA, BSA, and tetanus toxoid by ELISA. The test antigen was coated onto microtiter plates at $10-50 \mu \mathrm{g} / \mathrm{ml}$ in PBS (ssDNA was coated onto poly-L-lysine-treated plates). The plates were blocked as above and incubated sequentially with cell line supernatant, peroxidase-conjugated $\mathrm{Fab}^{\prime} 2$ goat anti-human IgM (Accurate) and 2,2'-azino-di-[3ethyl benzthiazoline sulfonate ] substrate. Cell line supernatants were tested by ELISA for reactivity with RF antiidiotypes Wa, 6B6.6 (a kind gift of Dr. W. Koopman, University of Alabama), 17.109 (kindly donated by Dr. P. P. Chen, University of California, San Diego), and 4 C9 as previously described (26).

Identification of $V L$ and $V H$ gene usage. Cell line RNA was tested for usage of the Vk and VH gene families by dot blot analysis. $10^{5}$ cells were lysed using 50\% DMSO in lysis buffer (2.5 M KSCN $0.01 \mathrm{M} \mathrm{Na}$ citrate, $0.01 \mathrm{M}$ Sarcosyl, $\mathrm{pH} 7.0$ ) and dotted in replicates of 10 onto nitrocellulose paper. The replicates were hybridized with each of 10 DNA probes specific for the Vk 1-4 and VH 1-6 families as previously described (24). All lines hybridized with only a single Vk and VH probe.

Amplification and isolation of the $V L$ and $V H$ gene segments. 1-5 $\mu \mathrm{g}$ of total RNA was reverse transcribed into cDNA using oligo-dT as the primer for the light chains and a primer specific for the 5 ' region of $\mathrm{Cu}$ (AD11) as the primer for the heavy chains. Second-strand synthesis and amplification were performed using the PCR. For the light chains the $3^{\prime}$ primer was specific for the $3^{\prime}$ end of $\mathrm{Ck}(\mathrm{AD} 10)$ and the $5^{\prime}$ primers were specific either for a conserved region of the VkI leader (for VkI or VkII-BD329) or the VkIII leader sequence (AD3). For the heavy chains the same $3^{\prime}$ oligonucleotide used for priming was also used in the PCR reaction. The $5^{\prime}$ primers used were specific for the leader sequence or first framework of $\mathrm{VH} 1, \mathrm{VH} 3$, or $\mathrm{VH} 4 .^{2} 30$ cycles of amplification were performed using the following conditions: denaturation at $94^{\circ} \mathrm{C}$ for $1 \mathrm{~min}$, annealing at $50-55^{\circ} \mathrm{C}$ for $1 \mathrm{~min}$, extension at $72^{\circ} \mathrm{C}$ for $2 \mathrm{~min}$. Two independent reverse transcription and PCR reactions were set up for each cell line to decrease the possibility of reverse transcriptase or PCR errors. PCR products were purified on a low melt agarose gel (Sigma Chemical Co., St. Louis, MO) and ligated directly into the TA cloning vector (Invitrogen, San Diego, CA) according to the manufacturer's instructions. The ligation mixture was used to transform bacteria according to the manufacturer's instructions. Positive colonies were identified by hybridization to the appropriate $\mathrm{VH}$ or VL DNA probe. Plasmid minipreps were prepared from $1.5 \mathrm{ml}$ of bacterial cultures using the alkaline lysis method and the fragments were sequenced in both directions using the Sequenase kit (United States Biochemical Corp., Cleveland, OH) and the SP6, T7 (Promega Corp., Madison, WI) and universal primers specific for the TA vector. For the light chains a probe specific for the 5 ' region of $\mathrm{Ck}$ (AD1) was also used for sequencing. At least two clones were sequenced for each PCR reaction. In some cases the PCR products were sequenced directly in DMSO using the Sequenase kit as previously described (24).

Amplification of germline VHI and VkIII genes. In order to determine whether the VH1-encoded RF heavy chains are somatically mutated or represent previously uncharacterized members of the VH1 gene family, we isolated germline $\mathrm{VH} 1$ genes from one of the patients, $R$, from whom we derived four VHI encoded RFs. Genomic DNA was obtained from neutrophils from the patient. The genes were amplified using a 5 ' oligonucleotide sequence homologous to a conserved VH1 leader sequence (AD12) and a 3' oligonucleotide that spans the $3^{\prime}$ end of $\mathrm{VH} 1$ and the heptamer sequence (AD13) of the subgroup of $\mathrm{VH} 1$ genes most homologous to the RF VH1 gene sequences we had obtained above (27). Three separate PCR reactions were performed using 1,10 , and $100 \mathrm{ng}$ of genomic DNA and the fragments were purified and subcloned as above. A total of 60 clones were sequenced in both directions as above.

Similarly, in order to analyze the six VkIII-encoded light chain sequences from patient $R$, genomic DNA from $R$ was amplified using the same conserved leader oligomer used in the PCR reactions (AD3) and a conserved $3^{\prime}$ flanking region sequence oligomer (AD14) homologous to the Humkv 325, 328, and $\mathrm{Vg}$ genes $(28,29)$. 30 clones were sequenced from four different libraries.

Analysis of somatic mutations using PCR and hybridization techniques. In order to show that the differences we observed in the complementarity determining regions (CDRs) from germline were due to so-

2. Oligonucleotide probes used for PCR and hybridization experiments are listed together with their origins.

\begin{tabular}{ll}
\hline Probe $\left(5^{\prime}-3^{\prime}\right)$ & Source \\
\hline
\end{tabular}

AD10 tccttctagattactaacactctccctgttgaagctctttgt- $\quad$ Ck

gacgggcgaactc

AD11 tgctgctgatgtcagagttgt

AD3 accagttgctacgctgctga

BD329 gtgccagatgtgagctcgtgatgacccagtctcca

BD292 caggtgcagctggtgcagtc

BD244 caggtgcagctgcaggagtc

BD276 caggtgcagctggtggagtc

BD324 agatctcaggctgctcagctc

BD332 gctgctcagttccatgtaggc

AD12 gggatcctcacactgtgtctctcgcac

AD1 3 ggatccatggactggacctggagg

AD1 4 taaaggaagcagctggtata

AD16 ttgtgttaccattgccagagt

AD17 agttcggtgtgccaaacatag

AD18 acctagctgtcccaaacattg

AD19 gcgtaatttgctgttccaaag

AD20 gcaaagtaggtgctgctgac

AD21 gctaaggaggttctgctaac

AD23 agtaggcatacccactgtta

AD25 caggctaagtagctgctaac

AD26 taagtagctgctaacagccg

AD27 acagtaatacactgcaaaa

AD29 cctggaaactctgtgaatat

AD30 gtggccctggtagatgcac

AD31 atgttattcagtcctgtgt

AD32 ctcttttggtggcagcagc
$\mathrm{Cu} \mathrm{CH} 1$

VkIII leader

VkI L/FRI

VH1 FR 1

VH4 FR1

VH3 FR1

51P1 FR3

B19H FR3

VH1 3' flank

VH1 leader

VkIII 3' flank

B19H CDR2 5

Ro7H CDR2

Ro47H CDR2

Re12H CDR2

Ro7k CDR 1

RC2k CDR 1

RC2H CDR2

Re12k CDR 1

Re12k CDR 1

Humkv 325 FR3

B19H CDR2'

Ro47k CDR2

Ro47H L intron

B19H L intron 
Table I. Summary of Characteristics of the 11 RF-producing Cell Lines

\begin{tabular}{|c|c|c|c|c|c|c|c|c|c|}
\hline Line & $\begin{array}{c}\text { Human } \\
\text { Fc }\end{array}$ & $\begin{array}{c}\text { Rabbit } \\
\text { Fc }\end{array}$ & $\begin{array}{l}\text { Tetanus } \\
\text { toxoid }\end{array}$ & ssDNA & BSA & $\mathrm{Vk}$ & Jk & VH & $\mathrm{JH}$ \\
\hline Ro7 & + & + & - & - & - & III & 4 & 1 & 4 \\
\hline Ro47 & + & + & - & - & - & II & 2 & 1 & 4 \\
\hline $\operatorname{Re} 12$ & + & + & - & - & - & III & 1 & 1 & 4 \\
\hline $\mathrm{R} 2$ & + & ND & ND & ND & - & II & 1 & 1 & 4 \\
\hline B19 & + & + & - & - & - & III & 5 & 1 & 5 \\
\hline $\mathrm{RCl}$ & + & + & + & + & $+1-$ & III & 3 & 3 & 4 \\
\hline $\mathrm{R} 1$ & + & ND & ND & ND & - & I & 5 & 3 & 4 \\
\hline RC6 & + & + & - & - & - & III & 5 & 4 & 4 \\
\hline $\mathrm{RC} 2$ & + & + & - & - & - & III & 2 & 4 & 2 \\
\hline B8 & + & + & ND & ND & - & III & 4 & 4 & 5 \\
\hline $\mathrm{RC} 4$ & + & + & - & - & - & I & 5 & 4 & - \\
\hline
\end{tabular}

Antigen-binding characteristics and $\mathrm{VH}, \mathrm{JH}, \mathrm{Vk}$, and $\mathrm{Jk}$ gene assignments are listed for each line. Insufficient supernatant was available from the $\mathrm{R} 1, \mathrm{R} 2$, and B8 lines for full testing. Binding is displayed as either positive ( $>3 \mathrm{SD}$ above a mean of 10 non-RF-secreting EBV lines) or negative ( $<2$ SD above a mean of 10 non-RF-secreting EBV lines). The RC4 line used a VH4 gene by dot blot but no PCR product was obtained. ND, not done.

matic mutation, oligonucleotide probes specific for some of the cell line CDRs were synthesized and used as 3' primers for PCR of cell line genomic DNA or CDNA and genomic DNA from the patients $R$ and $B$. In each case the $5^{\prime}$ primer used was the same as had been used in the original cell line cDNA PCR reaction. In some cases the oligonucleotide probes were also hybridized to amplified cell line cDNA and amplified genomic DNA from the patients at high stringency. The amplified PCR products were electrophoresed on a $1 \%$ agarose gel and transferred to Genescreen nylon membranes (New England Nuclear, Boston, MA). The blots were probed at melting temperature $5^{\circ} \mathrm{C}$ with radiolabeled oligomers in $5 \times \mathrm{SSC} / 7 \%$ SDS and washed at the same temperature in $2 \times$ SSC $0.2 \%$ SDS. The probes used are listed in footnote 2 .

\section{Results}

\section{Generation of and characterization of $B$ cell lines}

A total of 11 lines were analyzed from the two patients: 9 from patient $R$ and 2 from patient $B$. All of the lines were of the IgM $\mathrm{k}$ isotype. Seven of eight lines tested reacted only with human and rabbit Fc; one line, $\mathrm{RCl}$, was polyspecific, reacting only with BSA, ssDNA, and tetanus toxoid (Table I). Fine antigenic specificity of these RFs has been described in detail (23).

\section{Gene family assignments of heavy and light chain genes}

Dot blot analysis of $\mathrm{Vk}$ gene usage revealed that eight lines used a VkIII gene, while two used Vk1 and 1 used VkII. Analysis of VH gene usage revealed that five lines used a VH1 gene, four used VH4, and two used VH3. Light chain sequences were obtained for all 11 cell lines. Heavy chain sequences were obtained for 10 lines, but we were unable to obtain a PCR product for the $\mathrm{VH}$ of RC4 with any of our primers. The gene family assignments for $\mathrm{V}$ and $\mathrm{J}$ segments are summarized in Table $\mathrm{I}$. As can be seen, the lines are clonally unrelated.

\section{Sequences of the heavy and light chain genes}

The VL and VH gene assignments and percent homology to previously published germline gene sequences are summarized in Table II.

Light chains. The light chain $\mathrm{V}$ region sequences are shown in Figs. 1-3. Several features of interest were noted. Two lines use VkI light chains one of which, RC4, is $98.6 \%$ homologous to the $\mathrm{Vd}$ gene that is used to encode the KL1 RF reported by
Victor et al. (16). $\mathrm{R} 1$ is also homologous to Vd but its germline origin cannot be determined with certainty. In contrast, another line, R2, uses a VkII gene (Fig. 2) that is < 90\% homologous to either of the two VkII genes (A23 and K562) that have been previously reported to encode $\operatorname{RF}(16,30,31)$. Eight lines use VkIII genes (Humkv 325, Humkv 328, and Vg) that have been reported to encode RF derived both from patients with $B$ cell malignancies and from rheumatoid synovium. One of the lines, $\operatorname{Re} 12$, is missing an amino acid in CDR1 (Fig. 3, left). All the five different Jk segments are represented among the cell lines (Fig. 4). The length of CDR3 is either eight ( R1 and B19) or nine amino acids, with none having $\mathrm{N}$ region additions in CDR3.

Table II. Gene Assignments and Homologies of Heavy and Light Chain Genes to Germline Genes and Idiotypic Specificities of the Cell Lines

\begin{tabular}{|c|c|c|c|c|c|}
\hline \multirow[b]{2}{*}{ Line } & \multicolumn{2}{|c|}{ Heavy chains } & \multicolumn{2}{|c|}{ Light chains } & \multirow[b]{2}{*}{ Id } \\
\hline & VH & $\begin{array}{c}\text { Percent } \\
\text { homology }\end{array}$ & VL & $\begin{array}{c}\text { Percent } \\
\text { homology }\end{array}$ & \\
\hline R07 & $51 \mathrm{P} 1$ & 90.8 & Humkv 325 & 96.9 & Wa \\
\hline R047 & $51 \mathrm{P1}$ & 93.9 & Humkv 325 & 97.2 & Wa \\
\hline $\operatorname{Re} 12$ & $51 \mathrm{P} 1$ & 96.39 & Humkv 325 & 97.6 & $\mathrm{Wa} / 17.109$ \\
\hline R2 & HvlLls & 96.6 & VkII & & \\
\hline B19 & $1-13$ & 95.9 & Humkv 328 & 98.9 & \\
\hline $\mathrm{RCl}$ & 3005 & 96.9 & $\mathrm{Vg}$ & 99.3 & \\
\hline R1 & H11 & 95.2 & $\mathrm{Vd}$ & 91.6 & \\
\hline RC6 & VH4.22 & 94.6 & $\mathrm{Vg}$ & 96.8 & 4C9/6B6.6 \\
\hline $\mathrm{RC} 2$ & VH4.11 & 95.2 & Humkv 325 & 97.6 & \\
\hline B8 & VH4.18 & 93.6 & Humkv 328 & 95.8 & \\
\hline RC4 & VH4 & & Vd & 98.6 & \\
\hline
\end{tabular}

Gene assignments and percent homology to the nearest published germline gene heavy or light chain gene are listed. B19 heavy chain is most homologous to the newly characterized VH1 gene 1-13. Cell line supernatants were tested for reactivity with the antiidiotypes Wa, $17.109,6 \mathrm{~B} 6.6$, and $4 \mathrm{C} 9$. Only positive results for idiotypic specificity are shown. 


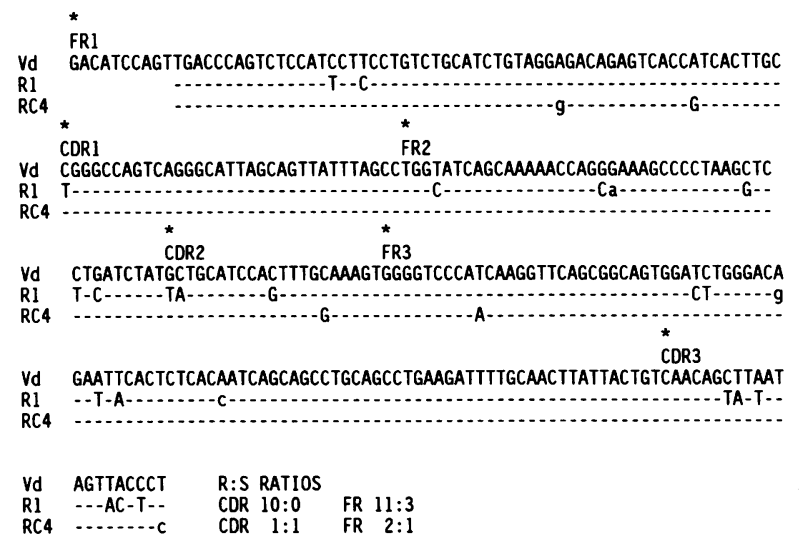

Figure 1. DNA sequences of VkI-encoded light chains compared with the Vd germline gene. Framework and CDR regions are marked according to the convention of Kabat and $\mathrm{Wu}$. The first nucleotide of each region is marked with an asterisk $\left({ }^{*}\right)$. Replacement mutations are shown in capital letters. Replacement to silent ratios of mutations ( $R: S$ ratios) compared to the most homologous germline gene are shown for each line for the CDRs and framework regions (FRs).

Heavy chains. The heavy chain $\mathrm{V}$ region sequences are shown in Figs. 5-7. Of the five lines that use VH1, one, B19, uses a VH1 gene that is $<90 \%$ homologous to previously published functional VH1 genes (Fig. 5) but 95.9\% homologous to the newly described VH1 gene 1-13 (see below). The three VH4 lines sequenced all use different members of the VH4 gene family (Fig. 7). The heavy chain $\mathrm{D}$ region sequences are shown in Fig. 8. There are some areas of homology between Ro7, Ro47, and Re12. The polyspecific RF, RCl, has the longest $\mathrm{D}$ region $(43 \mathrm{bp})$. The $\mathrm{JH}$ region sequences are shown in Fig. 9.7 of the 10 sequenced lines use the $\mathrm{JH} 4$ gene.

\section{Idiotypic reactivity of the cell lines}

The lines were tested for reactivity with the following previously described antiidiotypes: Wa, a polyclonal antiidiotype that recognizes a conformational determinant encoded by the Humkv 325 light chain gene most frequently in association with a VH1- or, rarely, a VH3-encoded heavy chain gene (32,

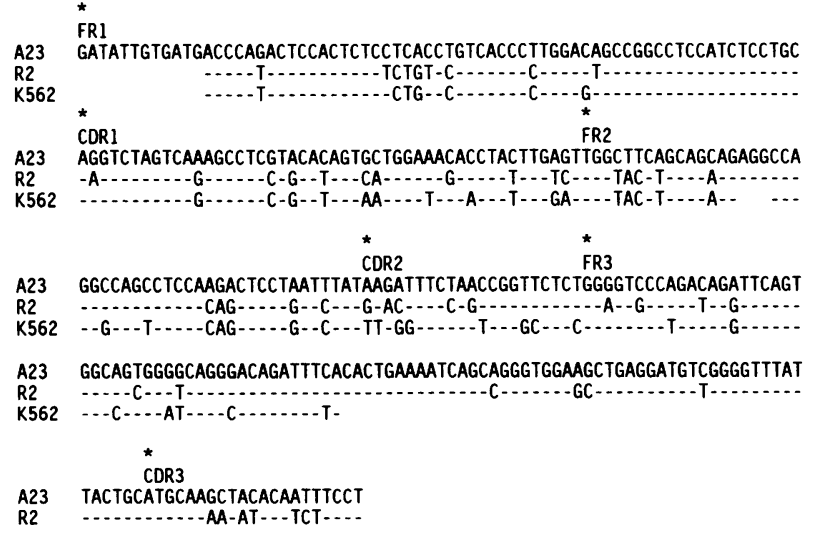

Figure 2. DNA sequences of the VkII-encoded light chain from R2 compared with the germline A23 and K562 genes that have can encode for RF activity. Because a framework 1 oligomer was used for the PCR reaction, sequence is reported only for the region 3 ' of the oligomer. Replacement and silent mutations are not shown because there is $<90 \%$ homology with either of the two germline genes.
33); 17.109, a monoclonal antiidiotype that recognizes light chains encoded by the Humkv 325 or Humkv 305 genes, often in association with a VH1 encoded heavy chain $(16,34)$; 6B6.6, a monoclonal antiidiotype that recognizes light chains encoded by the Humkv 328 gene, often in association with a VH4 encoded heavy chain (11); and 4C9, a monoclonal antiidiotype derived in our laboratory that recognizes a light chain determinant on RF from a majority of patients with RA (26).

Of the four lines that used the Humkv 325 light chain gene, three (Ro7, Ro47, and Re12) were reactive with the polyclonal Wa antibody but only one (Re12) expressed the 17.109 idiotype. Western blotting of the Ro7 and RC2 light chains confirmed that the isolated light chains reacted well with anti- $\kappa$ antibodies but were negative for 17.109 expression (not shown). One line, RC6, (encoded by a Vg light chain and a VH4 heavy chain) was positive for reactivity with both the 6B6.6 and 4C9 antibodies, but the B19 and B8 lines both of which use the Humkv 328 gene, were negative for the $6 \mathrm{~B} 6.6$ idiotype. The B8 line uses a VH4 gene typical of 6B6.6 malignancy-associated RFs, while the B19 line is encoded by a VH3 heavy chain. Western blotting of the isolated B19 light chain showed reactivity with an anti- $\kappa$ reagent but no reactivity with 6B6.6 (not shown). B19 uses a germline Jk5 segment, while B8 uses a germline Jk4. Together these data demonstrate that loss of expression of the 17.109 and 6B6.6 germline-encoded idiotypes can occur as a consequence of somatic mutation of the light chain $\mathrm{V}$ region genes.

\section{Analysis of somatic mutations using PCR and hybridization techniques}

In order to determine whether the differences we observed from the putative germline genes were due to somatic mutations or due to use of related but polymorphic or allelic $\mathrm{VH}$ and Vk genes, we undertook two different analyses of five selected cell lines, RC2, Ro7, Ro47, B19, and Re12, all of which are encoded by a VkIII light chain gene, and four of which use a VH1 heavy chain gene. First, oligonucleotide probes ( see footnote 2) homologous to the mutated CDRs of the cell lines were used to perform PCR at several temperatures on cell line genomic or cDNA and on genomic DNA from the patient from whom the cell line was derived. For each line we concluded that somatic mutations were present if a clear band of the appropriate size was shown for the cell line DNA but no band was seen for the genomic DNA at the same temperature. Using this method we found evidence for somatic mutations in the light chains of RC2, Ro7, Ro47, and Re12, and in the heavy chains of Ro47, Ro7, and RC2 (not shown). For some of the lines, we also used oligonucleotide probes for hybridization under highstringency conditions to PCR-amplified cell line DNA and to genomic DNA from the patients. Although the AD19 oligomer (together with $A D 13$ ) generated a $P C R$ product from patient $R$ genomic DNA, AD19 did not hybridize under high stringency conditions to patient R DNA amplified with AD13 and BD324 (Fig. $10 \mathrm{D}$ ) indicating that the Re12 CDR2 is mutated. The AD16 oligomer hybridized both to B19 and patient B genomic DNA amplified with AD13 and BD332, indicating that this sequence is present in the germline; however, the AD29 oligomer that is homologous to the more 3 ' end of B19 CDR2 hybridized only to B19 DNA (Fig. $10 \mathrm{~B}$ ), indicating that there are mutations in this area of the B19 CDR2.

We also used this hybridization method to determine whether the missing amino acid in CDR1 of Re12 was due to usage of a gene highly homologous to Humkv 325 or was due 

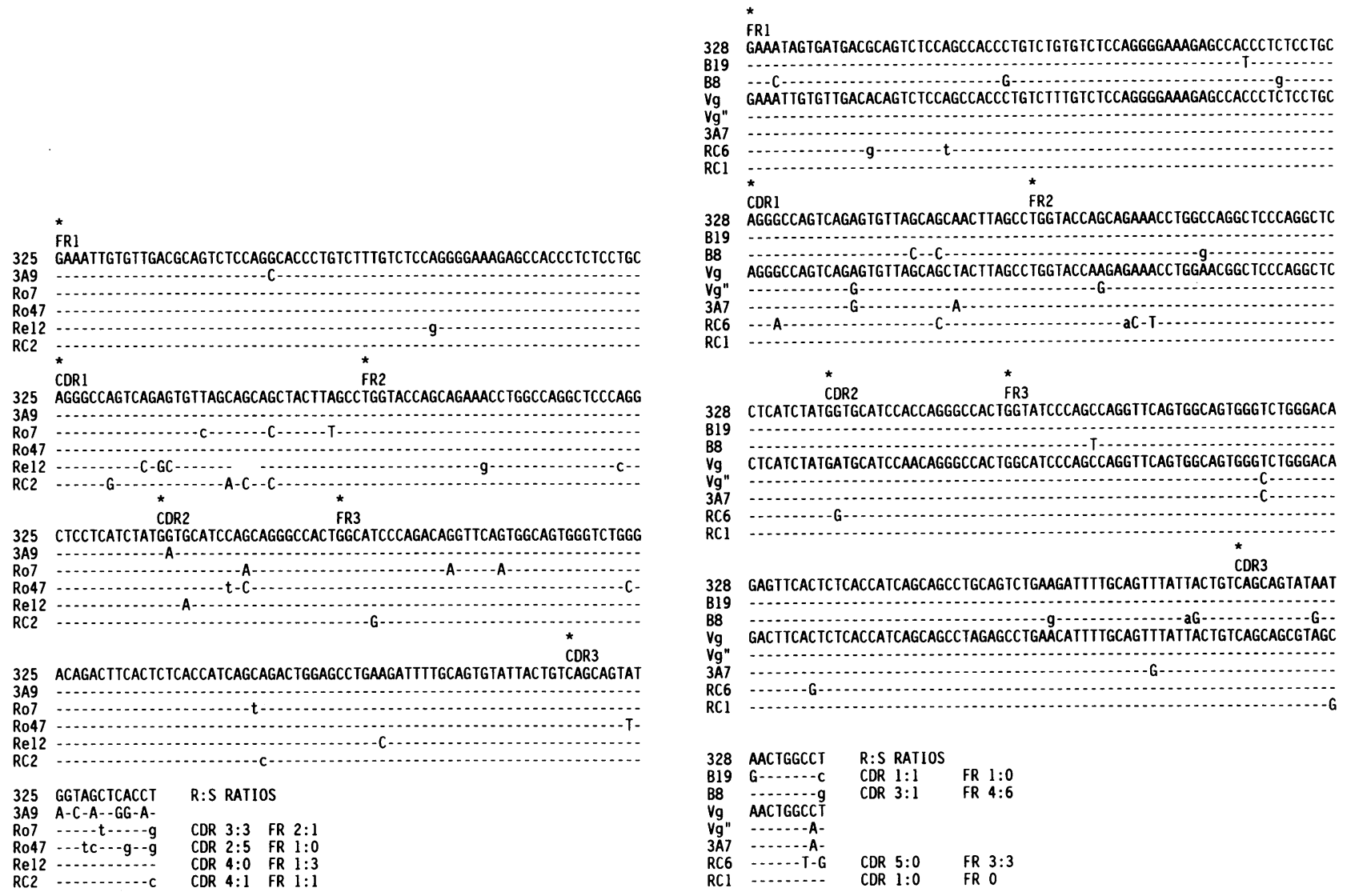

Figure 3. DNA sequences of the Humkv 325, Humkv 328, and Vg-encoded light chains compared with the corresponding germline genes. Replacement mutations are indicated in capital letters and R:S ratios are shown. Sequences of the newly defined germline genes 3A9 and 3A7 are respectively shown in the left and right panels. There is a three-nucleotide deletion in CDR1 of Re12.

to a somatic event. Oligonucleotide probes homologous to the Humkv 325 leader sequence and FR3 were used to PCR amplify genomic DNA from patient $\mathrm{R}$ and from Re12 and Ro47 cell line cDNA. Southern blotting was performed using the amplified DNA and the gels were probed either with the $\operatorname{Re} 12$ CDR1-FR2 oligonucleotide incorporating the deletion (AD25), with an Re12 CDR1 oligonucleotide incorporating three putative mutations (AD26), or with the Ro47 CDR2 oligonucleotide incorporating two mutations (AD 30). As can be seen in Fig. $10 \mathrm{~A}$, both AD25 and AD26 hybridized only to the Re12 DNA, while the third oligonucleotide corresponding to Ro47 CDR2 (AD30) hybridized only to Ro47. A VkIII

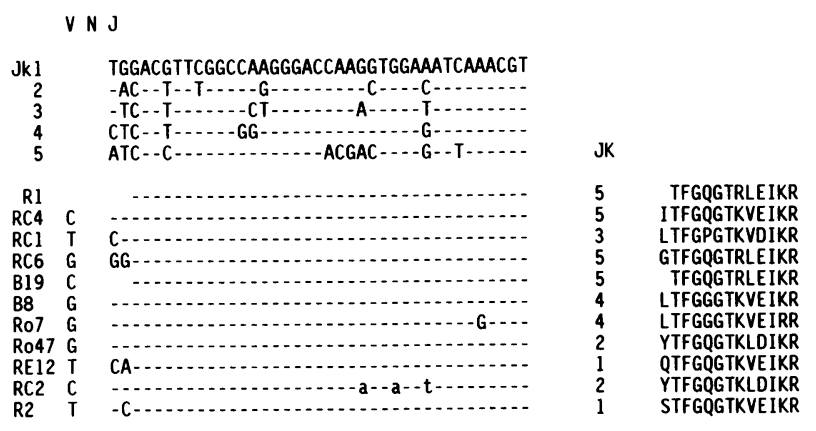

Figure 4. VJ junctions of the 11 light chains compared with germline $\mathrm{J}$ region genes. DNA sequences are shown on the left and amino acid sequences on the right. Replacement mutations are indicated in capital letters.
DNA probe hybridized equally to all three PCR products (not shown). This data suggests that the deletion seen in $\operatorname{Re} 12$ is not present in the germline of patient $R$, and may have been somatically acquired.

\section{Amplification of VHI and VkIII gene families}

The 51P1 gene, a member of the VH1 gene family, is used by three cell lines from patient $\mathbf{R}$. There are a number of different genes closely related to $51 \mathrm{P} 1$, some of which are allelic polymorphisms (35). The degree of polymorphism of the VkIII genes, used by six of the cell lines from patient $R$, is unknown. For this reason we decided to amplify members of the $\mathrm{VH} 1$ and VkIII gene families from patient $\mathbf{R}$ to determine the degree of polymorphism of the genes and to more accurately identify the germline origins of the RF cell line genes.

$V H 1$ genes. To analyze a selected subset of the $\mathrm{VH} 1$ genes of patient $R$, we amplified genomic $D N A$ from patient $R$ with a 5 ' oligonucleotide homologous to a conserved VH1 leader sequence (AD13), and a 3 ' oligonucleotide homologous to the end of FR3 and the heptamer of the 51P1 and Hv1L1 genes that most resemble the RF VH1 heavy chains (AD12). 60 clones were sequenced from three separate VH1 libraries. In addition to previously described $\mathrm{VH} 1$ genes $21-2,51 \mathrm{P} 1,1-1$, and the pseudogenes 201 and 65-1 (27), a total of seven new functional VH1 genes were isolated from patient $\mathrm{R}$ (not shown) from more than one PCR reaction. 1-1, previously reported as a pseudogene due to ambiguity in the sequence of one nucleotide, is a functional gene in patient $R$ (not shown). No new genes were identified that were more homologous to 
51P1 CAGGTGCAGCTGGTGCAGTCTGGGGCTGAGGTGAAGAaGCCTGGGTCCTCGGTGAagGTCTCCT

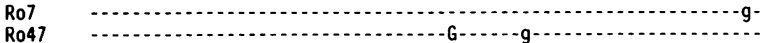

Re12
HvlL1
R2

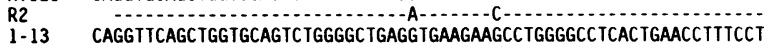

$B 19$

51P1 GCAGGCTICTGGAGGCACCTICAGCARI FR2

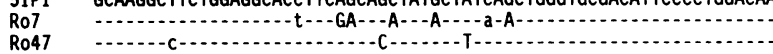

Ro47
Re12
$\cdots$

HvIL1 GCAAGGCTTCTGGATACACCTICACCGGCTACTATATGCACTGGGTGCGACAGGCCCCTGGACAA GCAAGGCTICTGGATACACCTICACTAGCTATGCTATGCATTGGG TGCGCCAGGCCCCCGGACAA CDR2

51P1 GGGCTTGAGtGGATGGGaGGGATCATCCCTATCTITGG TACAGCAAACTACGCACAGAAGITCCA -

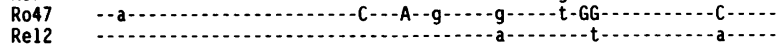
Hvll1 GGGCTTGAGTGGATGGGATGGATCACCCTAACAGTGGTGGCACAAACTATGCACAGAAGTITCA

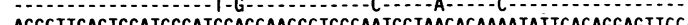

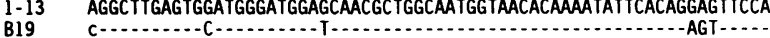
FR3

51P1 GgGCAGAGTCACGATTACCGCGGACGAaTCCACGAGCACAGCCTACATGGAGCTGAGCAGCCTGA Ro7 Ro47 Re12 $^{2}$ Rev1L1 GGGCAGGGTCACCATGACCAGGGACACGTCCATCAGCACAGCCTACATGGAGC TGAGCAGGCTGA $1-13$ GGGCAGAGICACCATIACCAGGGACACATCGGGAGCACAGCCTACATGGGC TGAGCAGCCTGA

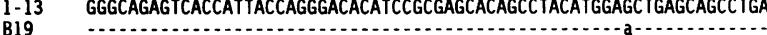

51P1 GATCTGAGGACACGGCCGTGTATIACTGTGCGAGA R:S RATIOS

CDR $7: 4$ FR 10:6

GatcigacGacacGeco-a.....

Hv1L1 GATCTGACGACACGGCCGTGTATTACTGTGCGAGA CDR $5: 0$ FR $2: 3$

1-13 GATCGGAGGACATGGTGIGTATIACTGIGCGAGA CDR 5:0 FR $2: 3$

Figure 5. DNA sequences of the VH1-encoded RF heavy chains compared with the most homologous germline genes, 51P1, Hv1L1, and $1-13$. Other $\mathrm{VH} 1$ germline genes highly homologous to $51 \mathrm{Pl}$ $(35,53,54)$ and to Hv1L1 (20) are not shown. Replacement mutations are indicated in capital letters and R:S ratios are shown. FR and CDR regions are marked according to the convention of Kabat and $\mathrm{Wu}$. The first nucleotide of each region is marked with *.

the Ro7, Ro47, R2, or Re12 heavy chain genes than the 51P1 or Hv1L1 genes. The heavy chain genes from Ro7 and Ro47 were subsequently obtained by PCR from cell line genomic DNA using AD13 and AD11 in order to examine the leader

$\stackrel{\star}{\text { FR } 1}$

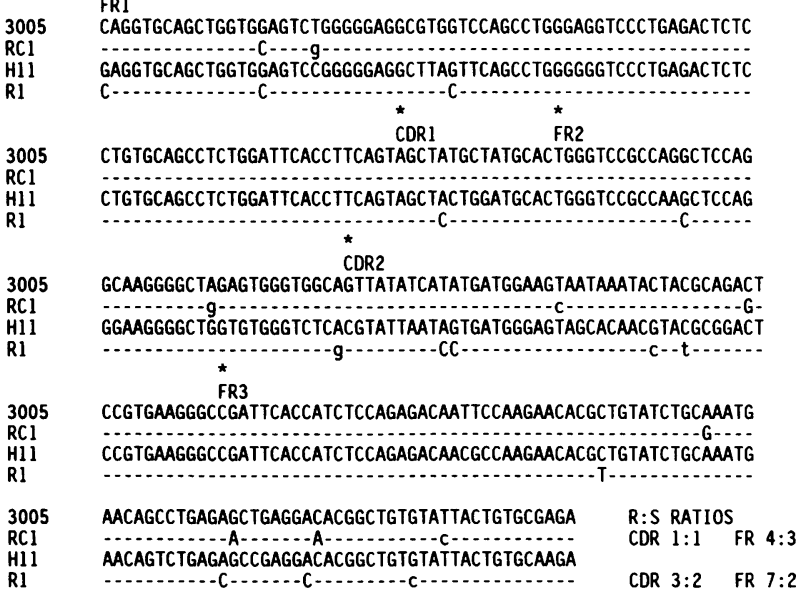

Figure 6. DNA sequences of the VH3 encoded heavy chains compared to their most homologous germline genes 3005 and H11. Replacement mutations are shown in capital letters and $\mathrm{R}: \mathrm{S}$ ratios are shown.
FR1

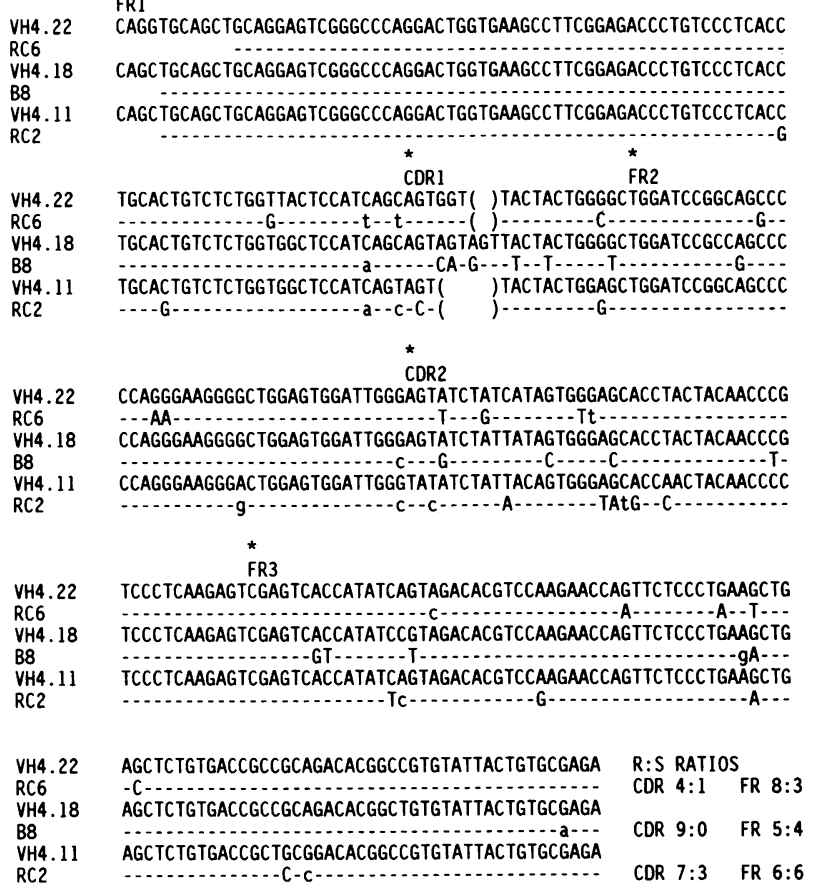

Figure 7. DNA sequences of the VH4 encoded RF heavy chains compared to the most homologous germline genes VH4.22, VH4.11, and VH4.18. Because a framework 1 oligomer was used for the PCR reactions the $5^{\prime}$ end of framework 1 is not included. Replacement mutations are shown in capital letters and $\mathrm{R}: \mathrm{S}$ ratios are shown.

introns. When the leader introns were compared with the 51P1 intron (36), one difference was found in the Ro7 DNA and six differences in the Ro47 DNA (not shown). ${ }^{3}$ An oligonucleotide probe spanning an area of differences in the Ro47 gene (AD28) was used to hybridize to PCR-amplified patient R genomic DNA and Ro47 cell line DNA. No hybridization was seen for the patient R genomic DNA (Fig. $10 C$ ), nor were we able to obtain a PCR product from patient $R$ genomic DNA when the AD28 oligomer was used as the 5 ' primer instead of AD13 (not shown). Together, these experiments indicate that $51 \mathrm{P} 1$ is the most likely germline gene for the Ro7 and Ro47 heavy chains. One of the new genes we obtained from patient $R$ was found to be highly homologous to the B19 heavy chain gene. Using an oligomer homologous to the leader intron of this gene (AD32), we were able to PCR the homologous gene, 1-13 from patient B (Fig. 5).

$V k I I I$ genes. Genomic DNA from patient $\mathrm{R}$ was amplified with the $5^{\prime}$ oligomer AD3 and two $3^{\prime}$ oligonucleotides, one homologous to the flanking region of all three VkIII genes of interest (AD14), and the other (AD9) homologous to FR3 of $\mathrm{Vg}$. Five independent VkIII genes were obtained multiple times from 30 clones sequenced from four separate PCR-amplified libraries. Three of these were $100 \%$ homologous to the previously described Humkv 325,328 , and $\mathrm{Vg}$ genes, respectively, and two are newly identified genes that are highly homologous to Humkv 305 (28) and $\mathrm{Vg}^{\prime \prime}(29)$ (Figs. 3 and 11). 3A9

3. The complete sequences of Ro7 and Ro47 heavy chains and of $3 A 7$ and $3 \mathrm{~A} 9$, including introns and $3^{\prime}$ flanking regions as well as all the sequences shown in this manuscript have been submitted to the Genbank Database and are available under accession numbers L19270-L19293. 


\begin{tabular}{|c|c|c|}
\hline $\begin{array}{l}\text { DXP'1 } \\
\text { DA4/1 } \\
\text { B19 }\end{array}$ & 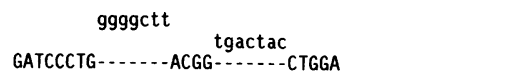 & DPWGLTVTTW \\
\hline $\begin{array}{l}\text { DQ52 } \\
\text { R2 }\end{array}$ & actgggg & TGG \\
\hline $\begin{array}{l}\text { D } 4 \text { Al } \\
\text { RI }\end{array}$ & $\begin{array}{c}\text { tctgctggggaa } \\
C C--T C--C G G\end{array}$ & PLSGNG \\
\hline $\begin{array}{l}\text { DK1 } \\
\text { RC2 }\end{array}$ & GAGGC--.9ct & EAVAGTGGW \\
\hline $\begin{array}{l}\text { DN1 } \\
\text { DK4 } \\
\text { Rel2 }\end{array}$ & $\begin{array}{c}\text { gggtat } \\
\text { GAA- }\end{array}$ & EGYPDTAMVNP \\
\hline Ro47 & ---GGTT---C--T-_-_CC-CGACGCCT & GWLDPSMATTP \\
\hline Ro7 & GGGTCGGGGAAC-C - - AA- - . - GGTGCC & GSGEHTNMVVP \\
\hline B8 & AGGGGGAC $\ldots . . .-G$ & RGDYRY \\
\hline $\begin{array}{l}\text { DXP'1 } \\
\mathrm{RC1}\end{array}$ & $\begin{array}{l}\text { cggggagttattat } \\
\text { GACGGTGATGTGGGTTC........-GC.....CC......CCTCTA }\end{array}$ & DVGSYGPGTYYPL \\
\hline RC6 & GACGACTTACTTAGCAGTTCA - C-C & DDLLSSSGTYS \\
\hline
\end{tabular}

Figure 8. DNA and amino acid sequences of heavy chain D regions compared with germline D regions. Germline D regions are lined up for maximal homology and are shown in small letters.

is probably a new VkIII gene that may have been generated as the result of a gene conversion event between a Humkv 305like gene and a $\mathrm{Vg}^{\prime \prime}$ gene (Fig. 11). The sequence is not a simiple chimera of Humkv 305 and $\mathrm{Vg}^{\prime \prime}$ generated as a result of PCR artefact because there are differences between 3A9 and both 305 and $\mathrm{Vg}^{\prime \prime}$ in the coding (Fig. 3) as well as in the flanking regions (not shown). ${ }^{3}$ We were unable to PCR the previously published $\mathrm{Vg}^{\prime}$ from $\mathrm{R}$. DNA, suggesting either that this gene is deleted in patient $R$, or that the $3 A 7$ gene is an allelic polymorphism of the $\mathrm{Vg}^{\prime \prime}$ gene. Comparison of the RF VkIII light chain sequences with these new genes, however, indicates that the Humkv 325, 328, and $3 \mathrm{~g}$ genes are the corresponding germline genes for the VkIII RF light chains.

\section{Discussion}

A variety of heavy and light chain genes are reported to be associated with RF activity in RA patients. Examination of published sequences of immunoglobulin light chain genes from monoclonal RF-producing B cell lines has demonstrated a predominance of light chains encoded by the VkIII gene family (9). Thus, of the 20 monospecific RFs from RA patients previously characterized at the molecular level, 13 have $\kappa$ light chains and 8 of them are encoded by VkIII genes $(9,18)$. In addition, 8 of the $11 \kappa$ light chains in our panel of cell lines are encoded by members of the VkIII gene family. In all, of the $24 \kappa$ light chain-bearing RFs from RA patients so far sequenced, 16 $(67 \%)$ are encoded by members of this gene family. Similarly, Newkirk and colleagues characterized a panel of monoclonal

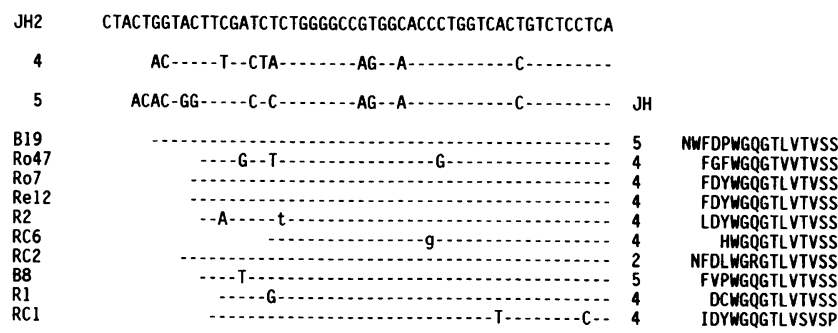

Figure 9. DNA sequences of $\mathrm{JH}$ genes compared with germline $\mathrm{JH}$ segments. Replacement mutations are shown in capital letters.
RFs from patients with RA and SLE using antipeptide and antiidiotypic antibodies and found that two thirds of the kappa bearing RFs from RA patients bore markers that assigned them to the VkIII gene family (36).

The VkIII gene family consists of at least eight or nine members (37) whose degree of polymorphism is unknown. The majority of RFs in the sera of patients with myeloma, cryoglobulinemia, or Waldenstrom's macroglobulinemia have light chains encoded by the Humkv 325 or 328 subtypes of VkIII and react with the monoclonal antiidiotypes 17.109 or 6B6.6 that are directed against the Humkv 325 (or 305) and 328 gene products, respectively (reviewed in reference 10 ). In contrast, serum RFs from RA patients rarely react with these antiidiotypes (14). Our RA patient cell lines include six lines encoded by the Humkv 325 or Humkv 328 genes, only one of which reacts with the 17.109 or $6 \mathrm{~B} 6.6$ monoclonal antiidiotypes. RC6, the only cell line that reacts with the $6 \mathrm{~B} 6.6$ antiidiotype, is encoded by another member of the VkIII gene family, $\mathrm{Vg}$. $\mathrm{Vg}$ genes have been isolated from synovial cDNA libraries $(38,39)$, and RFs using the $\mathrm{Vg}$ light chain have been previously described (40). No previous 6B6.6-reactive antibodies have been reported that are encoded by this gene, but $\mathrm{Vg}$ belongs to the VkIIIa subgroup that is highly homologous to Humkv 328 (29).

Somatic mutation of Humkv 325 and 328 genes has been described in cDNA libraries generated from RA peripheral blood B cells selected for RF activity and from RA synovium B cells, many of which are presumed to have RF activity (38, 39 ). In order to determine whether somatic mutation in our Humkv325- and 328-derived cell lines could account for the absence of reactivity with 17.109 and 6B6.6, we isolated and sequenced germline VkIII genes from patient $\mathbf{R}$. Our findings confirm that patient $\mathrm{R}$ has the Humkv 325,328 , and $\mathrm{Vg}$ genes in her germline, and that these are the appropriate genes for comparison with the cell line RF light chains. We also incidentally identified two new VkIII germline genes: 3A7, which is possibly a polymorphism of the $\mathrm{Vg}^{\prime \prime}$ gene, and $3 \mathrm{~A} 9$, which appears to have arisen as the result of a gene conversion-like event between KIIIa and KIIIb subgroup genes.

As shown in Fig. 3 (left), each cell line that uses a Humkv325-encoded light chain had three to five mutations from the germline gene. Of special interest is the amino acid deletion in CDR1 in the 17.109-positive line Re12. Although it is possible that our technique was not sensitive enough to detect a single unique germline gene, our hybridization experiments show that this most likely is the result of a somatic event, either a polymerase-induced error, or a recombination event. Somatic deletions of 1-14 nucleotides have previously been described in mouse myeloma cell lines (41), however, the possibility of repeated PCR error cannot be excluded. Examination of our lines and comparison with the previously reported 17.109-positive and -negative light chain amino acid sequences (10) is not informative as to the site of 17.109 binding. Although unreactive with 17.109 , three of our four Humkv 325-derived cell lines are reactive with the polyclonal antiidiotype, raised against the Wa monoclonal IgM RF protein, that recognizes a conformational determinant consisting of the Humkv 325 light chain and, most often, a VH1 heavy chain. The 17.109 and $\mathrm{Wa}$ antiidiotypes are thus directed to different epitopes on the light chain.

Similar analysis of the Humkv 328 encoded light chain genes reveals that somatic mutations are also present in the 6B6.6 negative Humkv328-encoded lines. The B19 line is po- 


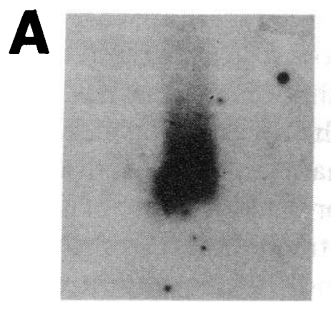

123
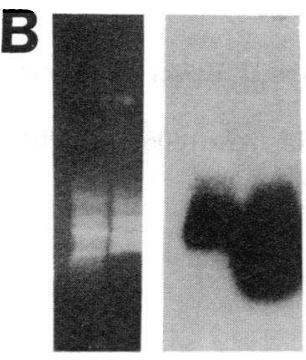

12

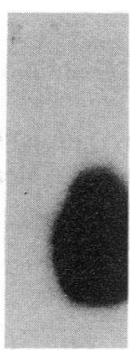

12

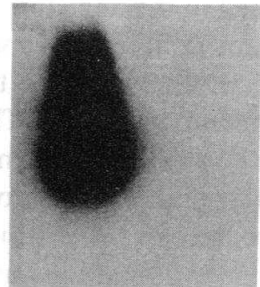

123

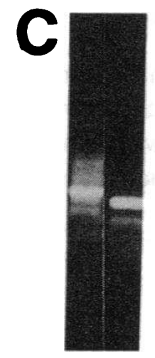

12

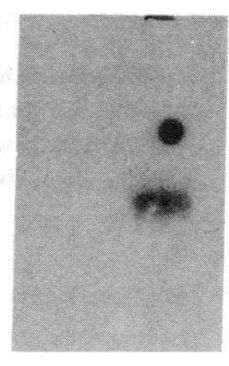

2
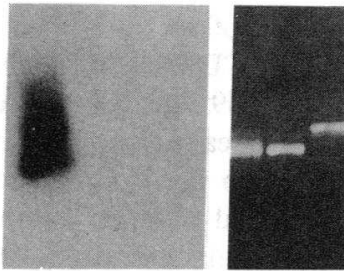

123123

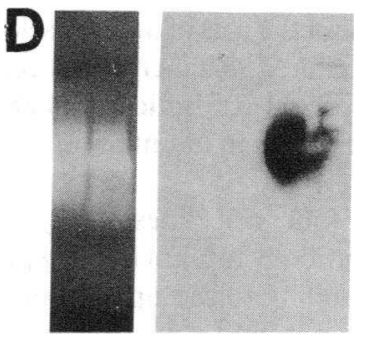

1212
Figure 10. Hybridization of specific oligonucleotide probes under high-stringency conditions to amplified cDNA or genomic DNA from the cell lines and the two patients. In all cases, concentration of the PCR products is shown in the ethidium bromide gel adjacent to each set of panels. $(A)$ Amplification primers $\mathrm{AD} 3$ and $\mathrm{AD} 27$ specific for VkIIIb genes. Lane 1, Re12 cDNA; lane 2, Ro47 cDNA; lane 3, patient R genomic DNA. Hybridization is shown for the Ro47 CDR2 specific oligomer AD30 (left panel), and the Re12 CDR 1 specific oligomers AD25 (middle panel) and AD26 (right panel). The band for the genomic DNA is larger because the leader intron is included in the PCR product. $(B)$ Amplification primers $\mathrm{AD} 12$ and $\mathrm{BD} 332$ specific for germline VH1. Lane 1 ,

patient B genomic DNA; lane 2, B19 cDNA. Hybridization is shown to two B19 CDR2 oligomers, AD16 (left panel) and AD29 (right panel). The AD16 sequence is present in the germline but the AD19 sequence is unique to B19. (C) Amplification primers are the 51P1-specific AD12 and BD324 for lane 1 (patient R genomic DNA) and the Ro47 specific AD12 and AD18 for lane 2 (Ro47 genomic DNA). Hybridization is shown to the Ro47 leader intron oligomer AD28. (D) Amplification primers are the 51P1 specific BD292 and BD324. Lane 1, patient R genomic DNA; lane 2, Re12 cDNA. Hybridization is shown to the Re12 CDR2 oligomer AD19.

tentially informative as it displays only two mutations in the light chain, an isoleucine for a threonine in FR1 and an aspartic acid for a serine in CDR3, both nonconservative changes. Single amino acid differences may result in the loss of both idiotypic and antigenic specificity $(42,43)$. It is clear from our findings that loss of reactivity with RF-associated idiotypes need not result in loss of RF activity. Site directed mutagenesis of the expressed B19 light chain may allow us to determine which of the amino acid changes noted here results in loss of 6B6.6 activity.

In addition to VkIII-encoded cell lines, our panel includes two VkI encoded light chain genes and one VkII-encoded gene that is sufficiently unlike the VkII genes that have previously been reported to encode $\operatorname{RF}(30,31)$ to allow us to conclude that multiple members of this gene family encode for RF specificity. The VkI and VkII gene families are not well characterized in humans, so that a mutational analysis of these genes was not feasible.

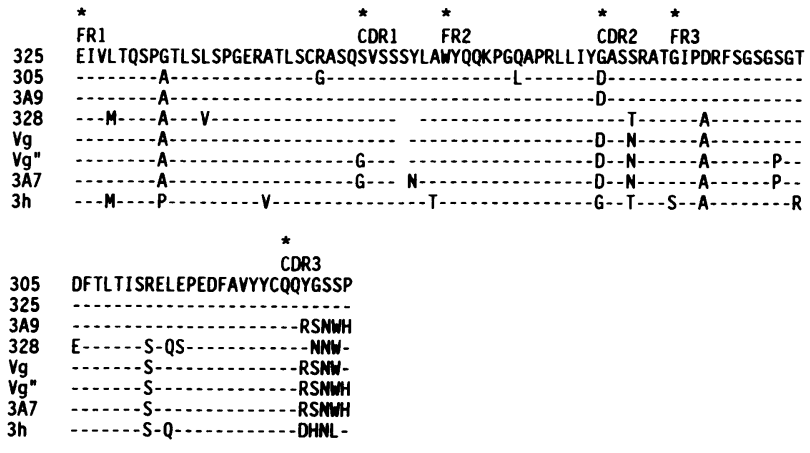

Figure 11. Deduced amino acid sequences of the known VkIII genes and the two newly identified VkIII genes, 3A7 and 3A9.
The RFs of RA patients appear to use a wider range of heavy chains than the RFs of malignancy. A skewing of the $\mathrm{RA}$-associated RF repertoire toward members of the $\mathrm{VH} 3$ gene family has been noted previously $(9,36)$, but this is not the case in our panel of nine cell lines from patient $R$. of which four use a member of the VH1 gene family, three use VH4, and only two use VH3. This finding suggests there may be marked heterogeneity in heavy chain gene usage by individual patients as well as differences in usage among patients. It is unlikely that the method used to derive the lines, EBV transformation, affects the repertoire, as most previously characterized RF-secreting lines are also derived by this method. The choice of RF-encoding genes in RA patients may depend on factors such as germline gene repertoire, allelic polymorphisms, and previous antigenic exposure.

Mutation analysis of the VH1-encoded cell line heavy chains indicates that these, like the light chains, have undergone varying degrees of change from the germline. $\mathrm{VH} 1$ is a large gene family with only a few well-characterized members. Our PCR-amplified library includes seven new VH1 genes, one of which, 1-13, is most likely the germline homologue of the B19 heavy chain. Three of our five VH1-encoded cell lines probably use the 51P1 gene although the two lines we examined in detail, Ro7 and Ro47, appear to have acquired mutations in the leader intron sequence. Mutations have been reported to occur in the leader intron sequence of mouse immunoglobulin at a rate similar to that found in the $\mathrm{V}$ regions, so that the presence of 1 mutation in Ro7 and 6 in the Ro47 86-bp leader introns, respectively, would not be an unexpected finding (41).

Examination of the pattern of replacement and silent mutations has been used to evaluate the role of antigen in selection of antibodies (44). In the four cell lines whose heavy and light chain germline origins we can identify with greatest confidence 
(Ro7, Ro47, Re12, and B19), analysis of the pattern of R:S ratios of mutations reveals a variable pattern. Most of our lines do not have more replacement mutations in the CDRs than would be generated by random mutation. The B19 line, for example, has a high $\mathrm{R}: \mathrm{S}$ ratio in the CDRs for the heavy chain (4:0), but has a lower relative avidity for Fc than the Ro7, Ro47, and Re12 lines (A. Davidson, unpublished observations) that have $\mathrm{R}: \mathrm{S}$ ratios in the CDRs consistent with random mutation. Because single mutations may result in significant differences in both antigenic and idiotypic specificity, an analysis of R:S ratios of mutations per se without information about the binding characteristics of the original germline-encoded antibody is not always informative about the role of antigen selection in generating antibodies with altered specificities. In contrast, the FRs have lower than expected R:S ratios, probably reflecting the need for conservation of FRs in maintaining antibody configuration.

We have reported that the four cell lines using the Humkv325 gene bind a chimeric antibody mutant bearing proline at residues 309-311, corresponding to the upper loop of the $\mathrm{CH} 2-\mathrm{CH} 3$ joining area, but do not bind a mutant bearing glycine in the same positions. This specificity was also found for the malignancy associated RFs that are positive for the Wa idiotype and are encoded by the Humkv 325 gene (23). Although they share this specificity, the three lines that use the same VH ( 51P1) and VL (Humkv 325) genes, Ro7, Re12, and Ro47, differ with respect to other specificities. For example, Ro7 binds only to IgG 1, 2, and 4, whereas Ro47 and Re12 bind to all four $\mathrm{IgG}$ isotypes. $\mathrm{Ro} 7 \mathrm{binding}$ to $\mathrm{Fc}$ is not inhibited by protein A, whereas Ro47 binding is completely inhibited and Re12 binding is partially inhibited (23). These differences must be attributed either to somatic mutations or to differences in the $\mathrm{DH}, \mathrm{JH}$, or Jk regions used to encode these RFs.

Our RF cell lines have substantial heterogeneity in portions of the immunoglobulin molecule other than the $\mathrm{V}$ gene segments. The heavy chain CDR 3 has been reported to contribute to RF specificity $(45,46)$. The heavy chain $\mathrm{D}$ regions of our panel vary widely in length and sequence and there are no obvious structural features common to all to which we can attribute RF activity. Some of the $\mathrm{D}$ regions appear to be fusions of two known $\mathrm{D}$ region genes, whereas others cannot be assigned a definite origin (47-49). It is of interest that the D regions of the three Wa-positive RFs are all 11 amino acids long and end with a proline, and that one of the three begins with a glutamine; these features that have been found for other Wa-positive heavy chain $\mathrm{D}$ regions (32). The $\mathrm{D}$ regions of the Wa-positive antibodies all share sequence homology with the germline DK4 gene, although the homology at the amino acid level is not obvious. Our panel of RF cell lines also show predominant use of the $\mathrm{JH} 4$ gene segment. This is the case with the three Wa-positive RFs and is consistent with previous observations that Wa-positive antibodies preferentially use this $\mathbf{J}$ region (32). Analysis of the light chain VJ joins shows that these also are heterogeneous. We did not observe any $\mathrm{N}$ region additions leading to long CDR3 regions or acquisition of arginine residues as has been observed for light chain genes derived from rheumatoid synovium cDNA libraries $(39,50) .2$ of the 11 light chains have short CDR3 regions of eight amino acids instead of the usual nine.

It is clear from the findings described here that the possible gene repertoire for encoding RF in our two patients with RA is large, includes multiple genes and gene combinations not found in malignancy-associated RFs, and is not restricted to genes used in the fetal antibody repertoire $(51,52)$. In the case of the gene families well enough characterized to permit analysis, our findings indicate that diversity arises at least in part from somatic mutation. The role of antigen in selecting these diverse B cells in RA remains unclear. A disturbance of the normal regulation of RFs or the emergence of abnormal $T$ cells may account for the recruitment of $B$ cells with different genes and gene combinations and the acquisition of mutations in these genes in RA patients.

\section{Acknowledgments}

The authors wish to thank Drs. B. Diamond and H. Keiser for critical review of the manuscript.

This work was supported by grants K08 AR01806 and P01 AI33184 from the National Institutes of Health.

\section{References}

1. Carson, D. A. 1989. Rheumatoid factor. In Textbook of Rheumatology. W. N. Kelley, E. D. Harris, S. Reddy, and C. B. Sledge, editor. W. B. Saunders Co., Philadelphia, PA. 198-207.

2. Carson, D. A., P. P. Chen, R. I. Fox, T. J. Kipps, F. Jirik, R. D. Goldfien, G. Silverman, V. Radoux, and S. Fong. 1987. Rheumatoid factor and immune networks. Annu. Rev. Immunol. 5:109-126.

3. Van Snick, J., and P. Coulie. 1983. Rheumatoid factors and secondary immune responses in the mouse. I. Frequent occurrence of hybridomas secreting IgM anti-IgGI autoantibodies after immunization with protein antigens. Eur. $J$. Immunol. 13:890-894.

4. Coulie, P., and J. Van Snick. 1983. Rheumatoid factors and secondary immune responses in the mouse. II. Incidence, kinetics and induction mechanisms. Eur. J. Immunol. 13:895-899.

5. Bellon, B., A. Manheimer, and C. Bona. 1985. Antiidiotype and anti-globulin antibodies two regulatory forces within the immune network. 9th International Convocation of Immunologists, Amherst, NY. S. Karger, Basel. 217-223.

6. Roosnek, E., and A. Lanzavecchia. 1991. Efficient and selective presentation of antigen antibody complexes by rheumatoid factor B cells. J. Exp. Med. 173:487-489.

7. Mannik, M., F. A. Nardella, and E. H. Sasso. 1988. Rheumatoid factors in immune complexes from patients with rheumatoid arthritis. Springer Semin. Immunopathol. 10:215-230.

8. Natvig, J. B., O. Forre, I. Randen, M. Steinitz, K. Thompson, and K. Waalen. 1988. B lymphocytes, B cell clines and rheumatoid factor antibodies in rheumatoid inflammation. Scand. J. Rheum. 76:217-227.

9. Sasso, E. H. 1992. Immunoglobulin V region genes in rheumatoid arthritis. Rheum. Dis. Clin. North Am. 18:809-836.

10. Chen, P. P., G. J. Silverman, M. F. Liu, and D. A. Carson. 1990. Idiotypic and molecular characterization of human rheumatoid factors. In Idiotypes in Biology and Medicine. D. A. Carson, P. P. Chen, and T. J. Kipps, editors. Chem. Immunol. 48:63-81.

11. Schrohenloher, R., M. A. Accavitti, A. S. Bhown, and W. J. Koopman. 1990. Monoclonal antibody 6B6.6 defines a crossreactive kappa light chain idiotope on human monoclonal and polyclonal rheumatoid factors. Arthritis Rheum. 33:187-198.

12. Crowley, J. J., R. D. Goldfien, R. E. Schrohenloher, H. L. Spiegelberg, G. J. Silverman, R. A. Mageed, R. Jefferis, W. J. Koopman, D. A. Carson, and S. Fong. 1988. Incidence of three crossreactive idiotypes on human rheumatoid factor paraproteins. J. Immunol. 140:3411-3418.

13. Silverman, G. J., R. E. Schrohenloher, M. A. Accavitti, W. J. Koopman, and D. A. Carson. 1990. Structural characterization of the second major crossreactive idiotype group of human rheumatoid factors. Arthritis Rheum. 33:1347-1360.

14. Koopman, W. J., R. E. Schrohenloher, and D. A. Carson. 1990. Dissociation of expression of two rheumatoid factor crossreactive $\mathrm{k}$ light chain idiotypes in rheumatoid arthritis. J. Immunol. 144:3468-3472.

15. Carson, D. A., P. P. Chen, T. J. Kipps, J. Roudier, G. J. Silverman, and H. Tighe. 1989. Regulation of rheumatoid factor synthesis. Clin. Exp. Rheumatol. 7(Suppl. 3):69-73.

16. Victor, K. D., I. Randen, K. Thompson, O. Forre, J. B. Natvig, S. M. Fu, and J. D. Capra. 1991. Rheumatoid factors isolated from patients with autoimmune disorders are derived from germline genes distinct from those encoding the Wa, Po and Bla cross-reactive idiotypes. J. Clin. Invest. 87:1603-1613.

17. Pascual, V., I. Randen, K. Thompson, M. Sioud, O. Forre, J. Natvig, and J. D. Capra. 1990. The complete nucleotide sequences of six monospecific RFs 
derived from EBV transformed B cells isolated from the synovial tissue of patients with rheumatoid arthritis. J. Clin. Invest. 86:1320-1328.

18. Ermel, R. W., T. P. Kenny, P. P. Chen, and D. L. Robbins. 1993. Molecular analysis of rheumatoid factors derived from rheumatoid synovium suggests an antigen-driven response in inflamed joints. Arthritis Rheum. 36:380-388.

19. Harindranath, N., I. S. Goldfarb, H. Ikematsu, S. E. Burastero, R. L. Wilder, A. L. Notkins, and P. Casali. 1991. Complete sequence of the genes encoding the $\mathrm{VH}$ and $\mathrm{VL}$ regions of low- and high-affinity monoclonal IgM and IgA1 rheumatoid factors produced by CD5+ B cells from a rheumatoid arthritis patient. Int. Immunol. 3:865-875.

20. Olee, T., E. W. Lu, D. F. Huang, R. W. Soto-Gil, M. Deftos, F. Kozin, D. A. Carson, and P. P. Chen. 1992. Genetic analysis of self-associating immunoglobulin $\mathrm{G}$ rheumatoid factors from two rheumatoid synovia implicates an antigen-driven response. J. Exp. Med. 175:831-842.

21. Randen, I., D. Brown, K. Thompson, N. Hughes-Jones, V. Pascual, K. Victor, J. D. Capra, O. Forre, and J. Natvig. 1992. Clonally related IgM rheumatoid factors undergo affinity maturation in the synovial tissue. J. Immunol. 148:3296-3301.

22. Artandi, S., K. L. Calame, S. L. Morrison, and V. R. Bonagura. 1992. Monorlonal IgM rheumatoid factors bind IgG at a discontinuous epitope comprised of amino acid loops from heavy chain constant region domains 2 and 3. Proc. Natl. Acad. Sci. USA. 89:94-98.

23. Bonagura, V., S. Artandi, A. Davidson, I. Randen, N. Agostino, K. Thompsen, K. J. Natvig, and S. Morrison. 1993. Molecular characterization of RA-derived monoclonal rheumatoid factor binding epitopes using genetically engineered chimeric IgG antibodies. J. Immunol. 151:3840-3852.

24. Manheimer-Lory, A., A. Davidson, D. Watkins, N. Hannigan, and B. Diamond. 1991. Generation and analysis of clonal IgM and IgG producing human B cell lines expressing anti-DNA associated idiotypes. J. Clin. Invest. 87:1519-1525.

25. Davidson, A., A. Manheimer-Lory, C. Aranow, R. Peterson, N. Hannigan, and B. Diamond. 1990. Molecular characterization of a somatically mutated anti-DNA antibody bearing two SLE related idiotypes. J. Clin. Invest. 85:14011409.

26. Davidson, A., J. Lopez, D. Prus, and D. Sun. 1992. A monoclonal antiidiotype specific for human polyclonal IgM rheumatoid factor. J. Immunol. 148:3873-3878.

27. Pascual, V., and J. D. Capra. 1991. Human immunogobulin heavy-chain variable region genes: organization, polymorphism and expression. $A d v$. Immunol. 49:1-74.

28. Chen, P. P., K. Albrandt, T. J. Kipps, V. Radoux, F. T. Liu, and D. A. Carson. 1987. Isolation and characterization of human VkIII germ-line genes. Implications for the molecular basis of human VkIII light chain diversity. $J$. Immunol. 139:1727-1733.

29. Pech, M., and H. Zachau. 1984. Immunoglobulin genes of different subgroups are interdigitated within the Vk locus. Nucleic Acids Res. 12:9229-9236.

30. Weisbart, R. H., A. L. Wong, D. Noritake, A. Kacena, G. Chan, C. Ruland, E. Chin, I. S. Y. Chen, and J. D. Rosenblatt. 1991. The rheumatoid factor reactivity of a human monoclonal autoantibody is encoded by a variant VkII L chain gene. J. Immunol. 147:2795-2801.

31. Stuber, F., S. K. Lee, S. L. Bridges, W. J. Koopman, H. W. Schroeder, F. Gaskin, and S. M. Fu. 1992. A rheumatoid factor from a normal individual encoded by VH2 and VkII gene segments. Arthritis Rheum. 35:900-904.

32. Andrews, E. M., and J. D. Capra. 1981. Complete amino acid sequence of variable domains from two monoclonal human anti-gamma globulins of the $\mathrm{Wa}$ cross idiotypic group: suggestion that the J segments are in the structural correlate of the idiotype. Proc. Natl. Acad. Sci. USA. 78:3799-3803.

33. Newkirk, M. M., R. A. Mageed, R. Jefferis, P. P. Chen, and J. D. Capra. 1987. Complete amino acid sequences of variable regions of two human IgM rheumatoid factors, BOR and KAS of the Wa idiotypic family, reveal restricted use of heavy and light chain variable and joining region gene segments. J. Exp. Med. 166:550-564.

34. Fong, S., P. P. Chen, T. A. Gilbertson, J. R. Weber, R. I. Fox, and D. A. Carson. 1986. Expression of three crossreactive idiotypes on rheumatoid factor autoantibodies from patients with autoimmune diseases and seropositive adults. J. Immunol. 137:122-128.

35. Sasso, E. H., K. W. van Dijk, A. P. Bull, and E. Milner. 1993. A fetally expressed immunoglobulin VH1 gene belongs to a complex set of alleles. J. Clin. Invest. 91:2358-2367.

36. Newkirk, M. M., J. Rauch, R. A. K. Mageed, R. Jefferis, D. N. Posnett, and G. J. Silverman. 1993. Restricted immunoglobulin variable region gene usage by hybridoma rheumatoid factors from patients with systemic lupus erythematosus and rheumatoid arthritis. Mol. Immunol. 30:255-263.

37. Meindl, A., H. G. Klobeck, R. Ohnheiser, and H. G. Zachau. 1990. The V gene repertoire in the human germ line. Eur. J. Immunol. 20:1855-1863.

38. Blaison, G., J. L. Kuntz, and J. L. Pasquali. 1991. Molecular analysis of VkIII variable regions of polyclonal rheumatoid factors during rheumatoid arthritis. Eur. J. Immunol. 21:1221-1227.

39. Lee, S. K., S. L. Bridges, Jr., W. J. Koopman, and H. W. Schroeder. 1992. Immunoglobulin kappa light chain repertoire in rheumatoid synovium. Arthritis Rheum. 35:905-913.

40. Siminovitch, K., and P. P. Chen. 1990. The biologic significance of human natural autoimmune responses: relationship to the germline, early immune and malignant B cell variable region gene repertoire. Int. Rev. Immunol. 5:265277.

41. Lebecque, S. G., and P. J. Gearhart. 1990. Boundaries of somatic mutation in rearranged immunoglobulin genes: $5^{\prime}$ boundary is near the promoter, and $3^{\prime}$ boundary is $1 \mathrm{~kb}$ from V(D)J gene. J. Exp. Med. 172:1717-1727.

42. Radbruch, A., S. Zaiss, C. Kappen, M. Bruggeman, K. Beyreuther, and K. Rajewsky. 1985. Drastic change in idiotypic but not antigen-binding specificity of an antibody by a single amino acid substitution. Nature (Lond.). 315:506-508.

43. Diamond, B., and M. D. Scharff. 1984. Somatic mutation of the T15 heavy chain gives rise to an antibody with autoantibody specificity. Proc. Natl. Acad. Sci. USA. 81:5841-5844.

44. Davidson, A. 1991. Somatic mutation. In Encyclopedia of Immunology. I. Roitt and P. Delves, editors. W. B. Saunders Co., Philadelphia, PA. 1381-1382.

45. Reininger, L., F. Spertini, T. Shibata, J. C. Jaton, and S. Izui. 1989. Rheumatoid factor autoantibody-binding site: a molecular analysis using monoclonal antibodies with dual anti-TNP and anti-IgG activities. Eur. J. Immunol. 19:2123-2130.

46. Martin, T., S. F. Duffy, D. A. Carson, and T. J. Kipps. 1992. Evidence for somatic selection of natural autoantibodies. J. Exp. Med. 173:983-991.

47. Buluwela, L., D. G. Albertson, P. Sherrington, P. H. Rabbitts, N. Spurr, and T. H. Rabbitts. 1988. The use of chromosomal translocations to study human immunoglobulin gene organization: mapping DH segments within $35 \mathrm{~kb}$ of the $\mathrm{C}$ gene and identification of a new DH locus. EMBO (Eur. Mol. Biol. Organ.) J. 7:2003-2010.

48. Ichihara, Y., H. Matsuoka, and Y. Kurosawa. 1988. Organization of human immunoglobulin heavy chain diversity gene loci. EMBO (Eur. Mol. Biol. Organ.) J. 7:4141-4150.

49. Sanz, I. 1991. Multiple mechanisms participate in the generation of diversity of human H chain CDR3 regions. J. Immunol. 147:1720-1729.

50. Martin, T., G. Blaison, H. Levallois, and J. L. Pasquali. 1992. Molecular analysis of the VkIII-Jk junctional diversity of polyclonal rheumatoid factors during rheumatoid arthritis frequently reveals $\mathrm{N}$ addition. Eur. J. Immunol. 22:1773-1779.

51. Schroeder, H. W., J. L. Hillson, and R. M. Perlmutter. 1987. Early restriction of the human antibody repertoire. Science (Wash. DC). 238:791-793.

52. Schroeder, H. W., and J. Y. Wang. 1990. Preferential utilization of conserved immunoglobulin heavy chain variable region gene segments during human fetal life. Proc. Natl. Acad. Sci. USA. 87:6146-6150.

53. Van Es, J. H., H. Aanstoot, F. Gmelig-Meyling, R. Derksen, and T. Logtenberg. 1992. A human systemic lupus erythematosus-related anti-cardiolipin single-stranded DNA autoantibody is encoded by a somatically mutated variant of the developmentally restricted 51P1 VH gene. J. Immunol. 149:2234-2240.

54. Ikematsu, H., N. Harindranath, and P. Casali. 1992. Somatic mutations in the $\mathrm{VH}$ genes of high affinity antibodies to self and foreign antigens produced by human CD5+ and CD5- B lymphocytes. Ann N.Y. Acad. Sci. 651:319-327. 